Cita, M.B., Stradner, H., and Ciaranfi, N., 1973. Biostratigraphical investigations on the Messinian stratotype and on the overlying "Trubi" marls: Riv. Ital. Pal. Strat., v, 79 , p. 397.

Clauer, N., 1976. ${ }^{87} \mathrm{Sr} /{ }^{86} \mathrm{Sr}$ composition of evaporitic carbonates and sulphates from Miocene sediment cores in the Mediterranean sea (DSDP Leg 13): Sedimentology, v. 23, p. 133.

Drooger, C.W. (Ed.), 1973. Messinian events in the Mediterranean. Kon. Nederl. Akad. Weten, Amsterdam (North Holland Publ. Comp.)

Dunoyer de Segonzac, G. and Nesteroff, W.D., in press, Les minéraux argileux dans le Messinien du bassin de Caltanissetta (Sicile): C.R. Acad. Sci., Paris.

Heimann, K.O. and Mascle, G., 1974. Les séquences de la série évaporitique messinienne: C.R. Acad. Sci., Paris, Ser. D, v. 279 , p. 1987

Kelts, K., 1973. Texture and mineralogy of some clastic sediments from site 133 - Western Sardinia slope. In Ryan, W.B.F., Hsü, K.J., et al., Initial Reports of the Deep Sea Drilling Project, Volume 13: Washington (U.S. Government Printing Office), p. 729.

Lucas, J., 1962. La transformation des minéraux argileux dans la sédimentation. Etudes sur les argiles du Trias: Mém. Serv. Carte géol. Alsace-Lorraine, v. 23, 202 p.

Millot, G., 1964. Géologie des Argiles. Masson Editor, Paris, $499 \mathrm{p}$.

Nesteroff, W.D., 1973a. Mineralogy, petrography, distribution and origin of the Messinian Mediterranean evaporites. In Ryan, W.B.F., Hsü, K.J., et al., Initial Reports of the Deep Sea Drilling Project, Volume 13: Washington (U.S. Government Printing Office), p. 673.
Pétrographie des évaporites messiniennes de la Méditerranée. Comparaison des forages JOIDES-DSDP et des dépôts du bassin de Sicile. In Drogger, C.W. (Ed.), Messinian events in the Mediterranean: Kon. Nederl. Akad. Weten.: Amsterdam (North Holland Publ. Comp.), p. 111.

Paquet, H., 1969. Evolution géochimique des minéraux argileux dans les altérations et les sols des climats méditerranéens et tropicaux à saisons contrastées. Mém. Serv. Carte géol. Alsace-Lorraine, v. 30, 212 p.

Pierre, C., 1974. Contribution à l'étude sédimentologique et isotopique des évaporites messiniennes de la Méditerranée: implications géodynamiques: Thèse 3ème cycle, Paris VI.

Ryan, W.B.F., Hsü, K.J., et al., 1973. Initial Reports of the Deep Sea Drilling Project, Volume 13: Washington (U.S. Government Printing Office).

Selli, R., 1960. Il Messinian Mayer-Eymar. Proposta di un Neostratotipo: Giorn. Geol., v. 28, p. 1.

Trauth, N., 1974. Argiles évaporitiques dans la sédimentation carbonatée tertiaire; Thèse, Sci. nat., Strasbourg.

Triat, J.-M. and Trauth, N., 1972. Evolution des minéraux argileux dans les sédiments paléogènes du bassin de Mormoiron (Vaucluse): Soc. franç Min. Crist. Bull., v. 95, p. 482.

Zemmels, I. and Cook, H.E., 1973. X-ray mineralogy studies of selected samples from the sea floor of the Northeast Atlantic and Mediterranean Sea. In Ryan W.B.F., Hsü, K.J., et al., Initial Reports of the Deep Sea Drilling Project, Volume 13: Washington (U.S. Government Printing Office), p. 605.

\title{
11.2 CLAY MINERALOGY IN VOLCANOGENIC SEDIMENTS
}

\author{
Hervé Chamley and Ghislaine Giroud d'Argoud, Centre d'Océanographie, Luminy, 13288 Marseille, France
}

\begin{abstract}
The clay minerals of volcanic glass-rich sediments from Hole $373 \mathrm{~A}$ and Site 376 are the same as those of their associated sediments. This confirms previous suggestions that submarine evolution of clay minerals from volcanogenic sediments is an unusual occurrence.
\end{abstract}

Volcanogenic sediments from DSDP Leg 42A were studied by $\mathrm{X}$-ray diffraction in order to determine if any postburial clay modification occurred in this peculiar depositional environment. Clay mineral compositions were determined for sediments from Sites 372 (East Menorca Rise, Cores 34 to 46); 373A (Central Tyrrhenian abyssal plain); and 376 (Florence Rise, west of Cyprus). The investigation of 48 samples from Site 372 did not confirm the presence of volcanic components as expected from initial shipboard descriptions of the lower Miocene clayey muds at the base of this section. Hence, those results will not be discussed here (see Mélières et al., this volume).
The data from the mineralogical study of the lessthan-2 micron noncalcareous particles are summarized in Tables 1 and 2 (values in percentages). The average values for "common" sediments, without volcanic components, are from analyses of the Pleistocene from Site 132 (DSDP Leg 12) for the Tyrrhenian Sea (Chamley, 1975a), and of sediments from Site 376 itself for the Levantine Basin.

Layers rich in volcanic glass occur at both sites (e.g., Samples 373A-1-1-111 cm, 376-1-5 $90 \mathrm{~cm}, 376-3-1$, $128 \mathrm{~cm}$ ). They are generally poor in clay minerals, whose relative abundances therefore cannot easily be determined. The horizons chiefly contain sandy glass: 
TABLE 1

Tyrrhenian Sea, Pleistocene, Hole 373A Clay Mineralogy (\%)

\begin{tabular}{|c|c|c|c|c|c|c|}
\hline $\begin{array}{l}\text { Sample } \\
\text { (Interval } \\
\text { in } \mathrm{cm} \text { ) }\end{array}$ & Hllite & Chlorite & $\begin{array}{l}\text { Mixed- } \\
\text { Layer }\end{array}$ & Smectite & Kaolinite & Attapulgite \\
\hline \multicolumn{7}{|l|}{$\begin{array}{l}\text { Volcanogenic } \\
\text { sediments }\end{array}$} \\
\hline $1-1,111$ & + & + & - & + & + & - \\
\hline $1-1,127$ & 35 & 10 & 10 & 35 & 10 & traces \\
\hline $1-2,136$ & 35 & 10 & 10 & 35 & 10 & - \\
\hline $1-3,146$ & 25 & 10 & 15 & 40 & 10 & traces \\
\hline \multicolumn{7}{|l|}{ Common sedi- } \\
\hline $\begin{array}{l}\text { ments (aver- } \\
\text { age values } \\
\text { Site 132) }\end{array}$ & 30 & 10 & 15 & 35 & 10 & traces \\
\hline
\end{tabular}

TABLE 2

Florence Rise, Pleistocene, Site 376 Clay Mineralogy (\%)

\begin{tabular}{ccccccc}
\hline $\begin{array}{c}\text { Sample } \\
\text { (Interval } \\
\text { in cm) }\end{array}$ & Illite & Chlorite & $\begin{array}{c}\text { Mixed- } \\
\text { Layer }\end{array}$ & Smectite & Kaolinite & Attapulgite \\
\hline $\begin{array}{l}\text { Volcanogenic } \\
\text { sediments }\end{array}$ & & & & & & \\
$1-5,90$ & + & + & $?$ & ++ & + & - \\
$1-5,95$ & 5 & 5 & 5 & 80 & 5 & $?$ \\
$1-5,98$ & 5 & 5 & 5 & 80 & 5 & traces \\
$3-1,128$ & + & + & $?$ & + & + & $?$ \\
$3-1,134$ & 5 & 5 & traces & 80 & 5 & 5 \\
Common & & & & & & \\
sediments & & & & & & \\
$1-5,106$ & 5 & 5 & traces & 80 & 5 & 5 \\
$3-1,146$ & 5 & 5 & traces & 80 & 5 & 5 \\
\hline
\end{tabular}

as splinters in Hole 373A and with both splintered and fibrous forms in Site 376. The levels without significant sand fractions contain clay mineral assemblages, the composition and crystallinity of which are quite similar to those of the under- and overlying "normal" sediments. It follows that there is no evidence of argillaceous diagenesis within a volcano-sedimentary environment at either drill site.

In order to place the present results in a more general context, we discuss below the much debated question of the early submarine transformation of volcanic materials to clay. Early studies carried out in the Tyrrhenian Sea lead workers to postulate the formation of clay minerals from volcanogenic minerals or ash. For example: The submarine exfoliation of biotite into illite in deep-sea pyroclastic sands (Norin, 1953); the transformation of glasses into montmorillonite, mixed-layer montmorillonite-illite, then illite and even chlorite in near-coast sands off Capri and Sardinia (Grim and Vernet, 1961); the formation of kaolinite, illite, quartz, calcedonite, and analcime in recently deposited ashes of the Gulf of Naples (Müller, 1961).

Later works commonly link the genesis of smectite (= montmorillonite) from volcanic materials. However, such a petrogenesis has not been clearly demonstrated. Moreover, a distinction is rarely made between submarine evolution and a continental transformation, by the weathering of a volcanic terrain producing smectite, which is ultimately, carried to the sea by river discharge (see Quakernaat, 1968). Thus Chamley et al. (1962) and then Nesteroff et al. (1963) suggested that the montmorillonite increase towards the south of the Tyrrhenian Sea could result from the development of volcanic rocks in this area, and such an idea is supported and developed by Tomadin $(1973,1974 a, b)$.
The above authors envisage a comparable relationship between smectite and volcanic rocks in the Central Mediterranean (see also Sartori and Tomadin, 1974), as well as in some sectors of the Eastern Mediterranean. In most cases, it is very difficult to distinguish between the different types of smectites in sediments (see Arrhenius, 1963; Griffin et al., 1968), all the more so because these minerals are available in abundance in numerous sedimentary rocks along the periphery of the Mediterranean (Chamley, 1971; Emelyanov, 1972). Valette (1972a), as well as Huang and Stanley (1972) and Pierce and Stanley (1975), consider the montmorillonite of the Alboran Sea to be the result of local volcanic evolution, but other workers believe it could also be inherited from the Atlantic by way of the Gibraltar Strait (Auffret et al., 1974; Mélières, 1974).

Some well-documented occurrences of authigenic mineralogical growth are known in the sediments of volcanic regions, and these would seem to support the previous results obtained in the Tyrrhenian Sea around 1960. Such is the case for palagonite or hyaloclastite formation, the genesis of spadaite and then saponite, zeolites with calcite and opal in Sicily (Honnorez, 1967), and the genesis of trioctahedric smectite with zeolites and calcite in Sicily and Campania (Cristofolini et al., 1973). Also, in the caldera of Santorini (Aegean Sea), clay-sized pumaceous ashes are transformed into smectite during burial, with the aid of silica from diatoms and radiolarians (Chamley and Millot, 1972). On the other hand, clays from the marine environs of Vulcano (Eolian Islands) do not seem to be clearly related to volcanism (Valette, 1972b).

The ash- or glass-bearing levels interbedded in common deep-sea sediments, similar to the ones considered here from DSDP Leg $42 \mathrm{~A}$, rarely show any characteristic authigenic clay mineral growths. It is commonly observed that the smaller smectite particles are in fact greatly diluted by the influx of the volcanic material. Other examples of this occurrence can be quoted: For example, pyroclastic layers in the eastern Mediterranean described by Ninkovich and Heezen (1965) and Keller and Ninkovich (1972), and studied mineralogically by Chamley (1971, 1975b) and Robert (1974); and volcanogenic sediments of DSDP Site 132 (Leg 13, Tyrrhenian Sea) described by Chamley (1975a).

The data presented here for the Leg $42 \mathrm{~A}$ sediments agree with those results from the literature discussed above that suggest that the authigenic formation of clay minerals in the Mediterranean volcano-sedimentary environment is not common. Such a petrogenesis is particularly unlikely in beds lacking siliceous fossil material or small volcanic particles with large surface areas as is the case in these sediments from Hole 373A and Site 376.

\section{ACKNOWLEDGMENTS}

This work was supported by the Grant $75 / 5155$ of the CNEXO, France. We are grateful to the shipboard team and especially to Dr. Frédéric Mélières for sampling the sediments for our studies. Dr. Kerry Kelts and Dr. Robert Kidd kindly reviewed the manuscript. 


\section{REFERENCES}

Arrhenius, G., 1963. Pelagic sediments. In Hill, M. N. (Ed.), The Sea: New York (John Wiley), v. 3, p. 692.

Auffret, G. A., Pastouret, L., Chamley, H., and Lanoix, F., 1974. Influence of the prevailing current regime on sedimentation in the Alboran Sea: Deep-Sea Res., v. 21, p. 839 .

Chamley, H., 1971. Recherches sur la sédimentation argileuse en Méditerranée: Sci. géol., Strasbourg, Mém. 35, p. 225.

Chamley H., 1975a. Sédimentation argileuse en mer Tyrrhénienne au Plio-Pléistocène d'après l'étude du forage JOIDES 132: Groupe franç. Arg. Bull., v. 27, p. 97. 1975b. Sédimentation argileuse en mer Ionienne au Plio-Pléistocène d'après l'étude des forages 125 DSDP: Soc. géol. France Bull., v. 17, p. 1131.

Chamley, H. and Millot, G., 1972. Néoformation de montmorillonite à partir de diatomées et de cendres dans les sédiments marins de Santorin (Méditerranée orientale): C. R. Acad. Sci., Paris, v. 274, p. 1132.

Chamley, H., Paquet, H., and Millot, G., 1962. Minéraux argileux de vases méditerranéennes: Serv. Carte géol. Als. Lorr. Bull., v. 15, p. 161.

Cristofolini, R., Di Girolamo, P., and Stanzione, D., 1973. Caratteri genetici e mineralogici di Ialoclastiti dell'Altopiano Ibleo (Sicilia) e dell'isola di Procida (Campania): Rendi conti Soc. Ital. Miner. Petr., v. 29, p. 497.

Emelyanov, E. M., 1972. Principal types of recent bottom sediments in the Mediterranean sea: their mineralogy and geochemistry. In Stanley, D. J. (Ed.), The Mediterranean Sea: Stroudsburg (Dowden, Hutchinson and Ross), p. 355.

Griffin, J. J., Windom, H., and Goldberg, E. D., 1968. The distribution of clay minerals in the World ocean: DeepSea Res., v. 15, p. 433.

Grim, R. E. and Vernet, J.-P., 1961. Etude par diffraction des minéraux argileux de vases méditerranéennes: Schweiz. Miner. Petr. Mitt., v. 41 , p. 65.

Honnorez J., 1967. La palagonitisation. Un aspect du volcanisme sous marin: l'altération du verre basique de Palagonia (Sicile): Thèse Univ. libre Bruxelles, p. 227.

Huang, T. C. and Stanley, D. J., 1972. Western Alboran Sea: sediment dispersal, ponding and reversal of currents. In Stanley, D. J., (Ed.), The Mediterranean Sea; (Dowden, Hutchinson and Ross), Stroudsburg, p. 521.

Keller, J. and Ninkovich, D., 1972. Tephra-Lagen in der Agais: Zeit., Deutsch., Geol. Ges., v. 123, p. 579.
Mélières, F., 1974. Recherches sur la dynamique sédimentaire du golfe de Cadix (Espagne): Thèse Sci. nat., Paris VI, p. 1-235.

Müller, G., 1961. Die rezenten Sedimente im Golf von Neapel. 2 - Mineral Neu- und Um-bildung in den rezenten Sedimenten des Golfes von Neapel: Beitr. Miner. Petr., v. 8, p. 1.

Nesteroff, W. D., Sabatier, G., and Heezen, B. C., 1963. Les minéraux argileux dans les sédiments du bassin occidental de la Méditerranée; Congr. Comm. Intern. Et. Sci. Méditerr. (CIESM), Monaco, v. 17, p. 1005.

Ninkovich, D., and Heezen, B. C., 1965. Santorini tephra. In Whittard, W. F. and Bradshaw, R (Ed.), Submarine geology and geophysics: Colston Pap., v. 17, p. 413.

Norin, E., 1953. Occurence of authigenous illitic mica in the sediments of the central Tyrrhenian sea: Geol. Inst. Univ. Uppsala Bull., v. 34, p. 279.

Pierce, J. W. and Stanley, D. J., 1975. Suspended-sediment concentration and mineralogy in the central and western Mediterranean, and mineralogic comparison with bottom sediment: Mar. Geol., v. 19, p. 15.

Quakernaat, J., 1968. X-ray analyses of clay minerals in some recent fluviatile sediments along the coasts of central Italy: Publ. fysisch-geografisch labo. Univ. Amsterdam, v. 12, p. 1-105.

Robert, C., 1974. Contribution à l'étude de la sédimentation argileuse en Méditerranée orientale: Thèse 3è cycle, AixMarseille II, p. 1-81.

Sartori, R. and Tomadin, L., 1974. Suspended mineral matter in the Northern Ionian Sea: Congr. Comm. intern. Et. Sci. Méditerr. (CIESM), Monaco, abstracts.

Tomadin, L., 1973. Minéraux argileux de vases tyrrhéniennes: Congr. Comm. Intern. Et. sci. Méditerr. (CIESM), Athènes, v. 21, p. 909.

1974a. Les minéraux argileux dans les sédiments actuels de la mer Tyrrhénienne: Groupe franç. Arg. Bull., v. 26 , p. 219.

1974b. Origin and dispersal of clay minerals in the Tyrrhenian Sea: Congr. Comm. Intern. Et. Sci. Méditerr. (CIESM), Monaco, abstracts.

Valette, J. N., 1972a. Etude minéralogique et géochimique des sédiments de mer d'Alboran: résultats préliminaires: C. R. Acad. Sci., Paris, v. 275 , p. 2287.

1972b. Etude sédimentologique et géochimique des dépôts littoraux entourant l'ile Vulcano (Italie). Rôle des fumerolles sous-marines dans les processus de néogenèse: Bur. Rech. Géol. Min. Bull., v. 4, p. 25.

\title{
11.3 TURBIDITES AT SITE 374: THEIR COMPOSITION, PROVENANCE AND PALEOBATHYMETRIC SIGNIFICANCE
}

\author{
Jens Müller, Werner Hieke, and Frank Fabricius, Lehrstuhl für Geologie, Technische Universitä,, \\ München, West Germany
}

\begin{abstract}
Pleistocene sediments cored at Site 374 in the Messina Abyssal Plain contain a number of turbidite deposits. Within these, two kinds of mineralogical associations were recognized. The first is low in carbonate with high amounts of quartz and feldspars, while the
\end{abstract}

